\title{
Classification of physiological races of Fusarium oxysporum f. sp. phaseoli in common bean
}

\author{
Francisco Humberto Henrique (1*); Sérgio Augusto Morais Carbonell ('); Margarida Fumiko Ito (2); \\ João Guilherme Ribeiro Gonçalves ('); Graziéle Ramos Sasseron ('); Alisson Fernando Chiorato (')
}

\author{
(1) Instituto Agronômico (IAC), Centro de Grãos e Fibras, Avenida Barão de Itapura, 1481, 13020-902 Campinas (SP), Brasil. \\ (2) IAC, Centro de Fitossanidade, 13020-902 Campinas (SP), Brasil. \\ $\left({ }^{*}\right)$ Corresponding author: franciscohhenrique@gmail.com
}

Received: Aug. 13, 2014; Accepted: Nov. 17, 2014

\begin{abstract}
Fusarium wilt, caused by Fusarium oxysporum Schlecht. f. phaseoli Kendrick and Snyder (FOP), is a major disease of common bean, causing large economic losses. Genetic resistance is one of the main mechanisms of pathogen control, and knowledge of the physiological variability is fundamental in breeding for resistant cultivars. Thus, a method of pathogen classification that describes the variability and is useful in plant breeding of isolates from different sources was evaluated by different methodologies. Common bean plants of different sets of differentiating cultivars were inoculated with 25 FOP isolates and 3 controls, totaling 28 isolates evaluated 30 days after inoculation. The variability in the isolates found in this study differs from the results of other authors, who reported a small number of physiological races of the pathogen and disagrees with their evaluation of the races and the evaluation methodology. The proposed approach for binary classification based on a group of 12 differentiating cultivars demonstrated that the variability in pathogenicity of FOP is greater than reported so far. By this methodology, 27 different physiological races of the pathogen were obtained. The methods led to contrasting results, with double race classification in the same isolate. The physiological variability found indicates that the physiological races of the pathogen are not limited to 7 as previously mentioned.
\end{abstract}

Key words: Fusarium wilt, Phaseolus vulgaris L., cultivars differential races, soil.

\section{INTRODUCTION}

Fusarium wilt, caused by Fusarium oxysporum Schlecht. f. sp. phaseoli Kendrick and Snyder (FOP), is a major disease of the common bean (Phaseolus vulgaris L.). The plants are invaded by the pathogen through the roots where the xylem is colonized, causing wilting, vascular discoloration, chlorosis, dwarfism, and premature plant death (Nelson et al., 1983). The disease can also be characterized by premature defoliation. Fusarium oxysporum is an anamorphic species identified by morphological criteria shared by both pathogenic and nonpathogenic strains (Bao et al., 2002). In the simplest form, 2 hyphas can fuse in anastomose and form a stable heterokaryon. This strain can be vegetatively compatible and in the same vegetative compatibility group (VCG) (Leslie \& Summerell, 2006). The pathogen survives in the soil in crop residues in the form of chlamydospores, which are resistance structures. There is also the hypothesis of survival in saprophytic state, forming heterokaryons with non-pathogenic FOP lines. Once the pathogen is introduced in a field, it is hardly retained by cultural practices, but the most viable and effective control practice is to use resistant cultivars
(Sartorato \& Rava, 1994). The difficulty of control is even greater since the pathogen has several physiological races. Various researches are studying the genetic diversity among Fusarium isolates to understand their genetic structure utilizing the determination of vegetative compatibility groups (VCGs); however, VCGs can contain the non-pathogenic isolates (Alves-Santos et al., 1999; Karimian et al., 2010; Woo et al., 1996). The utilization of differential cultivars is primordial to identify pathogenic races of FOP.

Seven pathogenic races are cited in the literature as related to geographical regions (Salgado et al., 1995). Race 1 was first identified in South Carolina (USA) and in Portici (Italy) (Ribeiro \& Hagedorn, 1979a), race 2 includes isolates from Brazil (Ribeiro \& Hagedorn, 1979b), race 3 occurs in Colombia (Salgado et al., 1995), race 4 consists of an isolate from Colorado (USA) (Salgado \& Schwartz, 1993), race 5 was identified in Greece (Kastoria) (Woo et al., 1996), race 6 in Spain, and race 7 in Greece (Chrysoupolis) (Alves-Santos et al., 2002). For the classification of FOP isolates, differentiating cultivars of the common bean are used. The classification 
of different races based on the sets of differentiating cultivars and especially on different assessment forms differs widely, because the same isolate can be classified differently by the different approaches. The difference between the methods used for FOP classification reflects the lack of identification of the variability.

According to the results reported in the literature, it is necessary to establish a new set of cultivars to differentiate FOP races, as a way of standardizing the method. Knowledge of different races is fundamental for common bean breeding programs for the selection for resistant genotypes.

The objective of this study was to identify the physiological races of Brazilian isolates of FOP and establish a new approach of classification of the physiological races of this fungus that would standardize the methods described in literature.

\section{MATERIAL AND METHOD}

Common bean plants with Fusarium wilt symptoms were collected in commercial production fields in the states of São Paulo, Goiás, Paraná and Santa Catarina in Brazil. To isolate FOP fragments of material, diseased tissue and healthy tissue of common bean plants were obtained from the transition region. The fragments were soaked in $70 \%$ ethanol, treated with $0.2 \%$ sodium hypochlorite for $90 \mathrm{sec}$, and transferred to Petri dishes containing PDA medium (Potato, Dextrose, Agar). These dishes were maintained in a BOD incubator at $27^{\circ} \mathrm{C} \pm 1{ }^{\circ} \mathrm{C}$ for 7 days in the dark.

From each FOP isolate obtained by incubation, spore cultures were established by plating conidial suspension on a PDA culture medium. By microscopy, a single conidium per plate was detected and the tips of the hypha from isolated colonies were further subcultured in test tubes containing PDA medium.

Then the surface of the colony was covered with sterile distilled water and the grown inoculum scraped off with a glass slide. The spore and mycelial suspensions were filtered through cheese cloth and the concentration adjusted to $1 \times 10^{6}$ conidia $\mathrm{mL}^{-1}$ (macro and microconidia) in a Neubauer chamber.

The pathogenicity of isolates was evaluated by inoculation of the FOP-susceptible common bean cultivars IAC-Alvorada and Rosinha $\mathrm{G}_{2}$. Seedlings of these cultivars were grown in trays with sterilized vermiculite, and 10 days after sowing the plants were inoculated by the dipping method, according to Costa et al. (1989). Cultivar IAC-Alvorada was used in tests to confirm the pathogenicity of the isolates. Only isolates that caused damage to both cultivars were considered, to reduce the risk of a misclassification.

To classify the pathogenic isolates of FOP in physiological races, 12 differentiating cultivars were used, 8 of which had been proposed by the International Center for Tropical Agriculture - CIAT: Mortińo, TIB 3042, Diacol Calima,
HF 465-63-1, RIZ 30, BAT 477, IPA 1 and A-211, and 4 by Nascimento et al. (1995): Preto Uberabinha, Bush Blue Lake 274, Tenderette, and IPA-6. Cultivars IAC-Alvorada and Rosinha $\mathrm{G}_{2}$ was used as susceptible control. The experiment was conducted in a greenhouse in pots, with a temperature of $25^{\circ} \mathrm{C} \pm 3{ }^{\circ} \mathrm{C}$, irrigated. All plants were grown from a single seed to ensure genetic purity, avoiding possible variations within cultivars and consequently in the classification of isolates.

The differentiating cultivars were sown in trays with sterilized vermiculite; 10 days after sowing the plants were inoculated according to Costa et al. (1989). The roots were washed, one third of the length cut off at the tip and immersed in the inoculum for $10 \mathrm{~min}$. After this, the plantlets were transferred to $500 \mathrm{~mL}$ flasks, containing organic compost substrate and soil, at 1:1. The experiment was arranged in a completely randomized design with 3 replications, and each plot consisted of 1 pot with 2 seedlings. We performed 3 repetitions of the same experiment to correct confirmation of susceptibility of differential plants for the inoculated isolates.

The disease symptoms were evaluated 30 days after inoculation, and the plants were classified as: resistant $(\mathrm{R})$ when the leaves showed no or little damage and susceptible (S) when wilting, highly damaged leaves or death of seedlings was observed. Also, the stem was cut at the plant base to check vessel darkening. The set of 12 differentiating cultivars was classified by 4 assessment methods:

Approach 1 - Nascimento et al. (1995) using the test cultivars: Preto Uberabinha, Tanderette, Bush Blue Lake 274, and IPA6;

Approach 2 - Woo et al. (1996) using the cultivars: Mortiño, TIB 3042, Diacol Calima, HF465-63-1, RIZ30, BAT 477, IPA 1, and A-211;

Approach 3 - Alves-Santos et al. (2002) using cultivars: A-211, BAT 477, Diacol Calima, IPA 1, and HF46563-1, the method currently used most in the literature; Approach 4 - An additional classification method was proposed based on uniqueness to standardize the 12 differentiating cultivars described above. This new approach was based on the use of binary values for each genotype and was also used to classify the anthracnose pathogen (Colletotrichum lindemuthianum (Sacc. and Magn.)).

The response of the cultivars to the pathogen was analyzed by the 3 classification methods (Table 1). The susceptibility of the differentiating cultivars was ranked, according to the pattern of susceptibility of each pathogen race, as described by Alves-Santos et al. (2002), Nascimento et al. (1995), Woo et al. (1996) and according to the order of differentiating plants established in the new approach, considering the resistance or susceptibility response, as mentioned.

In the approach 4 (Table 2), the sequence of cultivars was established on the basis of knowledge of differential cultivars 
Table 1. Reaction of common bean cultivars used in 3 methods races classification of Fusarium oxysporum f. sp phaseoli (Alves-Santos et al., 2002; Nascimento et al., 1995; Woo et al., 1996)

\begin{tabular}{|c|c|c|c|c|c|c|c|}
\hline \multirow{2}{*}{ Cultivars } & \multicolumn{7}{|c|}{ Race } \\
\hline & Race 1 & Race 2 & Race 3 & Race 4 & Race 5 & Race 6 & Race 7 \\
\hline A $211^{\mathrm{ab}}$ & S & S & $\mathrm{R}$ & S & S & S & $\mathrm{R}$ \\
\hline $\mathrm{RIZ} 30^{\mathrm{a}}$ & S & S & $\mathrm{R}$ & S & $S$ & - & - \\
\hline BAT $477^{\mathrm{ab}}$ & S & $\mathrm{R}$ & $\mathrm{R}$ & S & S & S & S \\
\hline Tenderette $^{c}$ & S & $\mathrm{R}$ & - & - & - & - & - \\
\hline BBL-274c & S & S & - & - & - & - & - \\
\hline IPA $6^{c}$ & S & S & - & - & - & - & - \\
\hline IPA $1^{\mathrm{ab}}$ & $\mathrm{R}$ & S & $\mathrm{R}$ & S & S & S & $\mathrm{R}$ \\
\hline Preto Uberabinhac & $\mathrm{R}$ & S & - & - & - & - & - \\
\hline TIB 3042a & $\mathrm{R}$ & $\mathrm{R}$ & S & S & S & - & - \\
\hline Diacol Calima $^{\mathrm{ab}}$ & $\mathrm{R}$ & $\mathrm{R}$ & S & $S$ & $\mathrm{R}$ & $\mathrm{S}$ & $S$ \\
\hline Mortiño ${ }^{a}$ & $\mathrm{R}$ & $\mathrm{R}$ & S & S & $\mathrm{R}$ & - & - \\
\hline HF $465-63-1^{\text {ab }}$ & $\mathrm{R}$ & $\mathrm{R}$ & $\mathrm{R}$ & $\mathrm{R}$ & $\mathrm{R}$ & S & $\mathrm{R}$ \\
\hline
\end{tabular}

${ }^{\text {a}}$ Used cultivars by Woo et al. (1996); ${ }^{b}$ Used cultivars by Alves-Santos et al. (2002); ' Used cultivars by Nascimento et al. (1995).

Table 2. Differential cultivars proposed for the classification of physiological races of F. oxysporum $\mathrm{f}$. sp. phaseoli

\begin{tabular}{|c|c|c|c|c|c|c|}
\hline \multirow{3}{*}{ Sequence } & \multirow{3}{*}{ Cultivars } & \multirow{3}{*}{ Binary value } & \multicolumn{4}{|c|}{ Major physiological races } \\
\hline & & & American & Brazilian & European & Greek \\
\hline & & & \multicolumn{4}{|c|}{ Reaction (R/S) } \\
\hline 1 & A 211 & 1 & $\mathrm{~S}$ & & & \\
\hline 2 & RIZ 30 & 2 & $\mathrm{~S}$ & & & \\
\hline 3 & BAT 477 & 4 & $\mathrm{~S}$ & & & \\
\hline 4 & Tenderette & 8 & $\mathrm{~S}$ & & & \\
\hline 5 & Bush Blue Lake & 16 & $\mathrm{~S}$ & $\mathrm{~S}$ & & \\
\hline 6 & IPA 6 & 32 & $\mathrm{~S}$ & $\mathrm{~S}$ & & \\
\hline 7 & IPA 1 & 64 & & $\mathrm{~S}$ & & \\
\hline 8 & Preto Uberabinha & 128 & & $\mathrm{~S}$ & & \\
\hline 9 & TIB 3042 & 256 & $\mathrm{R}$ & $\mathrm{R}$ & & \\
\hline 10 & Diacol Calima & 512 & $\mathrm{R}$ & $\mathrm{R}$ & $\mathrm{S}$ & $\mathrm{S}$ \\
\hline 12 & HF 456-63-1 & 2048 & & & $\mathrm{~S}$ & \\
\hline
\end{tabular}

to the major physiological races of Fusarium oxysporum f. sp. phaseoli catalogued in the literature. The cultivars were organized so that the first 4 genotypes A-211, RIZ 30, BAT 477, and Tenderette are susceptible to American race (Alves-Santos et al., 2002; Nascimento et al., 1995; Woo et al., 1996). The sequence to fifth and sixth genotypes were established for the genotypes Bush Blue Lake 274 and IPA-6, considered susceptible to both Brazilian and American races (Nascimento et al., 1995). The seventh and eighth position were established for the genotypes IPA-1 and Preto Uberabinha, considered susceptible only to the Brazilian race (Alves-Santos et al., 2002; Nascimento et al., 1995). After, the genotypes TIB 3042, Diacol Calima, and Mortiño, by presenting resistance to the American and Brazilian races (Alves-Santos et al., 2002; Woo et al., 1996) are on the ninth, tenth, and eleventh position, respectively. The tenth and the eleventh positions established in function of Diacol Calima and Mortiño are susceptible to the Greek and European races (Alves-Santos et al., 2002; Woo et al., 1996). The twelfth position was finalized by genotype
HF465-63-1 that has susceptibility only to European race (Alves-Santos et al., 2002; Woo et al., 1996). However, the cultivars' order was adapted to a more usual model of classification of FOP races that can be encompassed in all the variability of pathogen.

In the proposed sequence, the isolates classified with binary values lower than 63 were likely to be isolates from the American race, as described in the literature, since all differentiating cultivars are susceptible to this major physiological race. Classification values from 64 to 240 would include isolates of the Brazilian race, 241-1792 race 7 (Greek), and values above 1792 would be race 6 (European) isolates.

In the present paper, Embrapa Arroz and Feijão, located in Goiânia, GO, ceded 3 Brazilian pathogenics isolates, FOP 46, FOP 48, and FOP 42 of Fusarium oxysporum $\mathrm{f}$. sp. phaseoli identified in races 2,3 , and 6 , respectively, previously classified by Wendland et al. (2012) by metholodology of Alves-Santos et al. (2002) and utilized by others authors (Cândida et al., 2009; Pereira et al., 2002). These isolates 
were used for control and for comparison of reaction standard of resistance/susceptibility of total number of differential plants used in the approach 4, to allow comparisons between the methods used.

\section{RESULTS}

In separate analyses of each isolate by approaches 1 and 3 (Tables 3 and 4, respectively), it was observed that none of the isolate classifications agreed with approach 2 , by which all isolates were classified as unknown race (Table 5). Of the 25 isolates, 16 were classified in physiological races. By approach 1, isolates 18 and 19 were identified as Brazilian race and by approach 3 ,the same isolates were classified as race 7 , demonstrating the divergence between the methods.

When evaluated by the classification method of binary values (Table 6), no isolate was included in class 64-240, which should discriminate isolates of the Brazilian race (race 2 ), by the ranking of the differentiating plants according to their susceptibility described in the literature. Since all isolates had been collected in Brazil, it was expected that most would be classified as Brazilian races, but 10 isolates were grouped in class 241-1792 and 10 isolates classified over 1792, with isolates assigned to the races 6 and 7 . Only 3 of the isolates had values up to 63 , which were probably American. The data obtained confirm the existence of great physiological variability within the pathogen FOP.

Highest resistance was observed in cultivar A-211, with susceptibility to only 4 isolates. Cultivars TIB 3042 and IPA-1 were susceptible to only 6 and 7 isolates, respectively.

The results found by the new proposal (approach 4) indicate the failure of current methods to classify the physiologic races of FOP appropriately. Isolates previously classified as American (race 1), Brazilian (race 2), and races 3 to 7 did not remain within the established range by the new classification (Table 6). Seven isolates $(2,4,6,13,15,18$, and 19) of the 15 that had been classified by the methods of Alves-Santos et al. (2002), Nascimento et al. (1995) remained in the same range of classification of races by the proposed classification based on binary values (Table 7), whereas the other 8 isolates obtained other results, and no

Table 3. Reactions of differential common bean cultivars to races of Fusarium oxysporum f. sp. phaseoli, proposed by Nascimento et al. (1995) (Approach 1), the inoculation of monosporic isolates

\begin{tabular}{|c|c|c|c|c|c|}
\hline \multirow{2}{*}{ Isolates } & \multicolumn{4}{|c|}{ Differential Cultivars } & \multirow{2}{*}{ Race $^{*}$} \\
\hline & Preto Uberabinha & Tenderette & BBL-274 & IPA 6 & \\
\hline 01 & $\mathrm{R}$ & $\mathrm{R}$ & $\mathrm{S}$ & $\mathrm{S}$ & ur \\
\hline 02 & $\mathrm{R}$ & $\mathrm{R}$ & $\mathrm{R}$ & $\mathrm{R}$ & ur \\
\hline 03 & $\mathrm{~S}$ & $\mathrm{R}$ & S & $\mathrm{S}$ & br \\
\hline 04 & $\mathrm{R}$ & $\mathrm{R}$ & S & $\mathrm{R}$ & ur \\
\hline 05 & $\mathrm{~S}$ & $S$ & S & $\mathrm{S}$ & ur \\
\hline 06 & $\mathrm{R}$ & S & $\mathrm{R}$ & $\mathrm{R}$ & ur \\
\hline 07 & $\mathrm{~S}$ & $\mathrm{R}$ & S & $\mathrm{S}$ & br \\
\hline 08 & $\mathrm{~S}$ & S & S & S & ur \\
\hline 09 & $\mathrm{R}$ & $\mathrm{R}$ & $\mathrm{R}$ & $\mathrm{S}$ & ur \\
\hline 10 & $\mathrm{R}$ & S & $\mathrm{R}$ & $\mathrm{S}$ & ur \\
\hline 11 & $\mathrm{R}$ & S & S & $\mathrm{S}$ & am \\
\hline 12 & $\mathrm{R}$ & $S$ & $\mathrm{R}$ & $S$ & ur \\
\hline 13 & $\mathrm{~S}$ & $S$ & $\mathrm{R}$ & $S$ & ur \\
\hline 14 & $\mathrm{R}$ & $S$ & $S$ & $\mathrm{R}$ & am \\
\hline 15 & $\mathrm{R}$ & $S$ & $S$ & $\mathrm{R}$ & am \\
\hline 16 & $\mathrm{R}$ & $S$ & $\mathrm{R}$ & $\mathrm{R}$ & ur \\
\hline 17 & $\mathrm{R}$ & $S$ & S & $S$ & am \\
\hline 18 & $S$ & $\mathrm{R}$ & $S$ & $S$ & br \\
\hline 19 & $S$ & $\mathrm{R}$ & S & $S$ & br \\
\hline 20 & $S$ & $\mathrm{R}$ & $S$ & $S$ & br \\
\hline 21 & $S$ & $S$ & $S$ & $\mathrm{~S}$ & ur \\
\hline 22 & $\mathrm{R}$ & $S$ & $\mathrm{R}$ & $S$ & ur \\
\hline 23 & $\mathrm{R}$ & $\mathrm{R}$ & $S$ & $\mathrm{R}$ & ur \\
\hline 24 & $\mathrm{R}$ & $\mathrm{R}$ & $\mathrm{R}$ & $S$ & ur \\
\hline 25 & $\mathrm{R}$ & $\mathrm{R}$ & $\mathrm{R}$ & $S$ & ur \\
\hline Fop 42 & $\mathrm{R}$ & $\mathrm{R}$ & $\mathrm{R}$ & $\mathrm{S}$ & ur \\
\hline Fop 46 & $\mathrm{R}$ & $\mathrm{R}$ & $S$ & $S$ & ur \\
\hline Fop 48 & $S$ & $\mathrm{R}$ & $S$ & $S$ & ur \\
\hline
\end{tabular}

*br $=$ Brazilian; $\mathrm{am}=$ American; $\mathrm{ur}=$ undefined race. 
Table 4. Reactions of differential common bean cultivars to races of Fusarium oxysporum f. sp. phaseoli, proposed by Alves-Santos et al. (2002) (Approach 3), the inoculation of monosporic isolates

\begin{tabular}{|c|c|c|c|c|c|c|}
\hline \multirow{2}{*}{ Isolates } & \multicolumn{5}{|c|}{ Differential Cultivars } & \multirow{2}{*}{ Race* } \\
\hline & A-211 & BAT 477 & Diacol Calima & IPA 1 & HF 465-63-1 & \\
\hline 01 & $\mathrm{R}$ & $\mathrm{R}$ & $\mathrm{S}$ & $\mathrm{S}$ & $\mathrm{S}$ & ur \\
\hline 02 & $\mathrm{R}$ & $S$ & $S$ & $\mathrm{R}$ & $\mathrm{R}$ & 7 \\
\hline 03 & $\mathrm{R}$ & $\mathrm{s}$ & $\mathrm{R}$ & $\mathrm{R}$ & $\mathrm{R}$ & ur \\
\hline 04 & $\mathrm{R}$ & $S$ & $S$ & $\mathrm{R}$ & $\mathrm{R}$ & 7 \\
\hline 05 & S & $\mathrm{S}$ & $\mathrm{S}$ & $\mathrm{R}$ & $\mathrm{S}$ & ur \\
\hline 06 & $\mathrm{R}$ & $S$ & $S$ & $\mathrm{R}$ & $\mathrm{R}$ & 7 \\
\hline 07 & S & $\mathrm{S}$ & $\mathrm{S}$ & $\mathrm{R}$ & $\mathrm{R}$ & ur \\
\hline 08 & $\mathrm{R}$ & $\mathrm{S}$ & $\mathrm{R}$ & $\mathrm{S}$ & $S$ & ur \\
\hline 09 & $\mathrm{R}$ & $\mathrm{R}$ & $\mathrm{R}$ & $\mathrm{R}$ & $\mathrm{S}$ & ur \\
\hline 10 & $\mathrm{R}$ & $\mathrm{R}$ & $S$ & $S$ & $\mathrm{R}$ & ur \\
\hline 11 & $\mathrm{R}$ & $\mathrm{S}$ & $\mathrm{S}$ & $\mathrm{S}$ & $\mathrm{S}$ & ur \\
\hline 12 & $\mathrm{R}$ & $\mathrm{R}$ & $\mathrm{R}$ & $\mathrm{R}$ & $\mathrm{R}$ & ur \\
\hline 13 & S & $S$ & $S$ & S & $S$ & 6 \\
\hline 14 & $S$ & $S$ & $S$ & $\mathrm{R}$ & $S$ & ur \\
\hline 15 & $\mathrm{R}$ & $\mathrm{R}$ & $\mathrm{R}$ & $\mathrm{R}$ & $\mathrm{R}$ & ur \\
\hline 16 & $\mathrm{R}$ & $S$ & $\mathrm{R}$ & $\mathrm{R}$ & $\mathrm{R}$ & ur \\
\hline 17 & $\mathrm{R}$ & $\mathrm{R}$ & $\mathrm{S}$ & $\mathrm{S}$ & $S$ & ur \\
\hline 18 & $\mathrm{R}$ & $S$ & $S$ & $\mathrm{R}$ & $\mathrm{R}$ & 7 \\
\hline 19 & $\mathrm{R}$ & $S$ & $\mathrm{~S}$ & $\mathrm{R}$ & $\mathrm{R}$ & 7 \\
\hline 20 & $\mathrm{R}$ & $S$ & $\mathrm{R}$ & $\mathrm{R}$ & $S$ & ur \\
\hline 21 & $\mathrm{R}$ & $\mathrm{S}$ & $S$ & $\mathrm{~S}$ & $\mathrm{R}$ & ur \\
\hline 22 & $\mathrm{R}$ & $S$ & $\mathrm{R}$ & $\mathrm{R}$ & $\mathrm{R}$ & ur \\
\hline 23 & $\mathrm{R}$ & $\mathrm{R}$ & $\mathrm{R}$ & $\mathrm{R}$ & $\mathrm{R}$ & ur \\
\hline 24 & $\mathrm{R}$ & $S$ & $\mathrm{~S}$ & $\mathrm{R}$ & $\mathrm{R}$ & 7 \\
\hline 25 & $\mathrm{R}$ & $\mathrm{R}$ & $\mathrm{S}$ & $\mathrm{R}$ & $S$ & ur \\
\hline Fop 42 & $\mathrm{R}$ & $\mathrm{R}$ & $S$ & $\mathrm{R}$ & $\mathrm{R}$ & 3 \\
\hline Fop 46 & $\mathrm{R}$ & $\mathrm{R}$ & $S$ & $\mathrm{R}$ & $\mathrm{R}$ & 3 \\
\hline Fop 48 & $\mathrm{R}$ & $\mathrm{R}$ & $S$ & $\mathrm{R}$ & $\mathrm{R}$ & 3 \\
\hline
\end{tabular}

*ur= undefined race.

isolate previously classified as race 2 (Brazilian) remained in this range of classification.

The binary values of the isolates $2,4,6,18$, and 19 , classified as race 7 by approach 3 , were in the range between 241 to 1792 , with isolates of this same race. The binary value of isolate 13, also classified as race 6 by approach 3, was above 1792, identifying isolates of race 6. Likewise, isolate 15 had been classified as race 1 (American) by approach 1 , and the binary value was in the range up to 63 .

The isolates 1, 5, 7, 8, 11, 13, 14, 17, 18, 19, 20, and 21 were the most pathogenic (Table 6) and resulted in the death of at least 8 of the 12 cultivars. The most pathogenic isolate 5 infected 11 cultivars that were susceptible.

The genotypes RIZ 30, TIB 3042, HF 465-63-1, and Preto Uberabinha reacted with susceptibility when inoculated with 10 isolates. The cultivars most susceptible to the greatest number of isolates were Tenderette, Diacol Calima, Mortińo, BBL-274, IPA-6, and BAT 477. High susceptibility of IPA-6 was expected, as previously stated by IPA (1996), Miranda et al. (1996), Nascimento et al. (1995). IAC-Alvorada and Rosinha $G_{2}$ were susceptible to all isolates.
The inoculation of control isolates, FOP 42, FOP 46, and Fop 48 and the approaches 1, 2, and 3 did not indentify the races previously classified by Wendland et al. (2012), proving that there is not actually an efficient group of race differential cultivars.

Using approach 3, the 3 isolates used as control were classified as race 3 (Table 4). In approach 2, the isolates were classified in: FOP 42, undefined race, and the isolates FOP 46 and FOP 48 were classified in race 3 of pathogen (Table 5).

\section{DISCUSSION}

The group of FOP isolates evaluated in this study had been collected in important common bean-producing regions of Brazil. Other races than the Brazilian (race 2) and American (race 1) were found, indicating that the existing variability is not restricted to these 2 races, as previously suggested by Alves-Santos et al. (2002), Woo et al. (1996). Note that cultivar HF 465-63-1 was susceptible to 10 isolates (1, 5, $8,9,11,13,14,17,20$, and 25$)$, showing that these could 
Table 5. Reactions of differential common bean cultivars to races of Fusarium oxysporum f. sp. phaseoli, proposed by Woo et al. (1996) (Approach 2), the inoculation of monosporic isolates

\begin{tabular}{|c|c|c|c|c|c|c|c|c|c|}
\hline \multirow[b]{2}{*}{ Isolates } & \multirow[b]{2}{*}{ A-211 } & \multirow[b]{2}{*}{ RIZ 30} & \multirow[b]{2}{*}{ BAT 477} & \multicolumn{2}{|c|}{ Differential Cultivars } & \multirow[b]{2}{*}{ IPA 1} & \multirow[b]{2}{*}{ TIB 3042} & \multirow[b]{2}{*}{$\begin{array}{c}\text { HF 465- } \\
63-1\end{array}$} & \multirow[b]{2}{*}{ Race } \\
\hline & & & & Mortiño & $\begin{array}{l}\text { Diacol } \\
\text { Calima }\end{array}$ & & & & \\
\hline 1 & $\mathrm{R}$ & $\mathrm{S}$ & $\mathrm{R}$ & $\mathrm{S}$ & $\mathrm{S}$ & $\mathrm{S}$ & $\mathrm{S}$ & $\mathrm{S}$ & ur \\
\hline 2 & $\mathrm{R}$ & $\mathrm{R}$ & $\mathrm{S}$ & $\mathrm{R}$ & $S$ & $\mathrm{R}$ & $\mathrm{R}$ & $\mathrm{R}$ & ur \\
\hline 3 & $\mathrm{R}$ & $\mathrm{S}$ & $\mathrm{S}$ & $\mathrm{S}$ & $\mathrm{R}$ & $\mathrm{R}$ & $\mathrm{R}$ & $\mathrm{R}$ & ur \\
\hline 4 & $\mathrm{R}$ & $\mathrm{R}$ & $\mathrm{s}$ & $\mathrm{R}$ & $S$ & $\mathrm{R}$ & $\mathrm{R}$ & $\mathrm{R}$ & ur \\
\hline 5 & $\mathrm{~S}$ & $\mathrm{~S}$ & $\mathrm{~S}$ & $\mathrm{R}$ & $\mathrm{S}$ & $\mathrm{R}$ & $\mathrm{S}$ & $\mathrm{S}$ & ur \\
\hline 6 & $\mathrm{R}$ & $\mathrm{R}$ & $S$ & $S$ & $S$ & $\mathrm{R}$ & $\mathrm{R}$ & $\mathrm{R}$ & ur \\
\hline 7 & $\mathrm{~S}$ & $\mathrm{~S}$ & $\mathrm{~S}$ & $\mathrm{~S}$ & $\mathrm{~S}$ & $\mathrm{R}$ & $\mathrm{S}$ & $\mathrm{R}$ & ur \\
\hline 8 & $\mathrm{R}$ & $S$ & $S$ & $S$ & $\mathrm{R}$ & $S$ & $\mathrm{R}$ & $S$ & ur \\
\hline 9 & $\mathrm{R}$ & $\mathrm{R}$ & $\mathrm{R}$ & $S$ & $\mathrm{R}$ & $\mathrm{R}$ & $\mathrm{R}$ & $S$ & ur \\
\hline 10 & $\mathrm{R}$ & $\mathrm{R}$ & $\mathrm{R}$ & $\mathrm{R}$ & $S$ & $S$ & $\mathrm{R}$ & $\mathrm{R}$ & ur \\
\hline 11 & $\mathrm{R}$ & $\mathrm{R}$ & $S$ & $S$ & $S$ & $S$ & $\mathrm{R}$ & $S$ & ur \\
\hline 12 & $\mathrm{R}$ & $\mathrm{R}$ & $\mathrm{R}$ & $\mathrm{R}$ & $\mathrm{R}$ & $\mathrm{R}$ & $\mathrm{R}$ & $\mathrm{R}$ & ur \\
\hline 13 & $S$ & $\mathrm{R}$ & $S$ & $\mathrm{R}$ & $S$ & $S$ & $\mathrm{R}$ & $S$ & ur \\
\hline 14 & $S$ & $\mathrm{R}$ & $S$ & $S$ & $S$ & $\mathrm{R}$ & $S$ & $S$ & ur \\
\hline 15 & $\mathrm{R}$ & $\mathrm{R}$ & $\mathrm{R}$ & $\mathrm{R}$ & $\mathrm{R}$ & $\mathrm{R}$ & $\mathrm{R}$ & $\mathrm{R}$ & ur \\
\hline 16 & $\mathrm{R}$ & $S$ & $S$ & $S$ & $\mathrm{R}$ & $\mathrm{R}$ & $\mathrm{R}$ & $\mathrm{R}$ & ur \\
\hline 17 & $\mathrm{R}$ & $\mathrm{R}$ & $\mathrm{R}$ & $S$ & $S$ & $S$ & $S$ & $S$ & ur \\
\hline 18 & $\mathrm{R}$ & $S$ & $S$ & $S$ & $S$ & $\mathrm{R}$ & $\mathrm{R}$ & $\mathrm{R}$ & ur \\
\hline 19 & $\mathrm{R}$ & $S$ & $S$ & $S$ & $S$ & $\mathrm{R}$ & $\mathrm{R}$ & $\mathrm{R}$ & ur \\
\hline 20 & $\mathrm{R}$ & $S$ & $S$ & $S$ & $\mathrm{R}$ & $\mathrm{R}$ & $\mathrm{R}$ & $S$ & ur \\
\hline 21 & $\mathrm{R}$ & $\mathrm{R}$ & $\mathrm{S}$ & $\mathrm{R}$ & $\mathrm{S}$ & $\mathrm{S}$ & $S$ & $\mathrm{R}$ & ur \\
\hline 22 & $\mathrm{R}$ & $\mathrm{R}$ & $S$ & $\mathrm{R}$ & $\mathrm{R}$ & $\mathrm{R}$ & $\mathrm{R}$ & $\mathrm{R}$ & ur \\
\hline 23 & $\mathrm{R}$ & $\mathrm{R}$ & $\mathrm{R}$ & $S$ & $\mathrm{R}$ & $\mathrm{R}$ & $\mathrm{R}$ & $\mathrm{R}$ & ur \\
\hline 24 & $\mathrm{R}$ & $\mathrm{R}$ & $S$ & $\mathrm{R}$ & $S$ & $\mathrm{R}$ & $\mathrm{R}$ & $\mathrm{R}$ & ur \\
\hline 25 & $\mathrm{R}$ & $\mathrm{R}$ & $\mathrm{R}$ & $\mathrm{R}$ & $\mathrm{S}$ & $\mathrm{R}$ & $S$ & $S$ & ur \\
\hline Fop 42 & $\mathrm{R}$ & $\mathrm{R}$ & $\mathrm{R}$ & $\mathrm{R}$ & $\mathrm{S}$ & $\mathrm{R}$ & $S$ & $\mathrm{R}$ & ur \\
\hline Fop 46 & $\mathrm{R}$ & $\mathrm{R}$ & $\mathrm{R}$ & $S$ & $\mathrm{~S}$ & $\mathrm{R}$ & $S$ & $\mathrm{R}$ & 3 \\
\hline Fop 48 & $\mathrm{R}$ & $\mathrm{R}$ & $\mathrm{R}$ & $S$ & $\mathrm{~S}$ & $\mathrm{R}$ & $S$ & $\mathrm{R}$ & 3 \\
\hline
\end{tabular}

${ }^{*}$ ur $=$ undefined race.

possibly be isolates of race 6 , as described by Alves-Santos et al. (2002), who classified the isolates of this race based on the susceptibility of HF 465-63-1, but, when applying only approach 2, as proposed by Alves-Santos et al. (2002), it was not possible to classify the isolate as race 6 because of the differences in patterns of resistance/susceptibility.

The presence of isolates classified as race $7(2,4,18$, and 19) was also proven, bearing in mind that there is a greater number of physiological races of FOP causing Fusarium wilt in Brazil.

The nomenclature of races based on geographical regions is rather misleading, because up to 4 physiological races are found in the same region. In America (Brazil, Colombia, and the United States), Ito et al. (1997), Woo et al. (1996) found 9 physiological races. Therefore, a more precise and accurate classification can better represent the variability of the pathogen, demonstrating that races classified according to the regional occurrence can be found in other regions as well. Race 1 (American) is an example of this result, having been identified in South Carolina (USA) as well as in Portici in Italy, as published by Ribeiro \& Hagedorn (1979a).
It should be emphasized that the classification ranges are used for comparison with other methods, since the purpose of the new approach is a region-independent, more comprehensive classification system to cover the large variability in the pathogen.

This new set of common bean cultivars differentiating FOP races was proposed due to several attempts to classify FOP isolates, which failed to standardize the classification of physiological races as described in the literature.

The isolates used as control, previously classified by group of differential cultivars proposed by Alves-Santos et al. (2002), FOP 42, FOP 46, and FOP 48 as races 6, 2, and 3, respectively, by Wendland et al. (2012), were not classified again in the same physiological races; when comparing the 4 proposals used, the classification does not remain the same. This fact also occurred with the isolate 24 as approaches 1 and 2 presented undefined races; when evaluated by approach 3 , it was classified as race 7 (Tables 3, 4, 5).

Inoculations were repeated 3 times per approach to eliminate possible assessment errors, thus avoiding the misclassification of races. The 3 approaches were grouped 


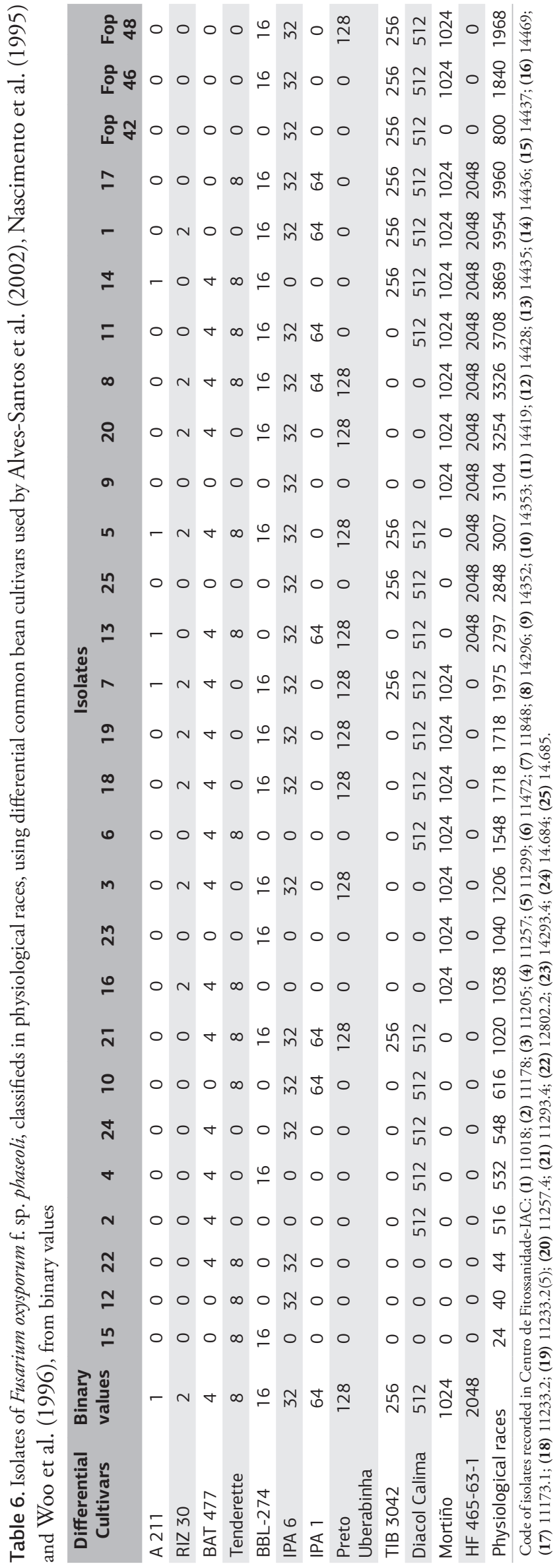


Table 7. Comparison of the classification of physiological races of Fusarium oxysporum f. sp. phaseoli by the methods used by AlvesSantos et al. (2002) and Nascimento et al. (1995)

\begin{tabular}{|c|c|c|c|}
\hline Isolates & Classification of races & Expected binary value & Obtained binary value \\
\hline $2^{c}$ & $7^{\mathrm{b}}$ & 241 to 1792 & 516 \\
\hline 3 & $2^{\mathrm{a}}$ & 64 to 240 & 1206 \\
\hline $4^{c}$ & $7^{\mathrm{b}}$ & 241 to 1792 & 532 \\
\hline $6^{c}$ & $7^{b}$ & 241 to 1792 & 1548 \\
\hline 7 & $2^{\mathrm{a}}$ & 64 to 240 & 1975 \\
\hline 11 & $1^{\mathrm{a}}$ & up to 63 & 3708 \\
\hline $13^{c}$ & $6^{\mathrm{b}}$ & above 1792 & 2797 \\
\hline 14 & $1^{\mathrm{a}}$ & up to 63 & 3869 \\
\hline $15^{c}$ & $1^{\mathrm{a}}$ & up to63 & 24 \\
\hline 17 & $1^{\mathrm{a}}$ & up to 63 & 3960 \\
\hline 18 & $2^{\mathrm{a}}$ & 64 to 240 & 1718 \\
\hline $18^{\mathrm{c}}$ & $7^{b}$ & 241 to 1792 & 1718 \\
\hline 19 & $2^{\mathrm{a}}$ & 64 to 240 & 1718 \\
\hline $19^{c}$ & $7^{b}$ & 241 to 1792 & 1718 \\
\hline 20 & $2^{\mathrm{a}}$ & 64 to 241 & 3254 \\
\hline $24^{c}$ & $7^{b}$ & 241 to 1792 & 548 \\
\hline Fop 42 & 6 & above 1792 & 800 \\
\hline Fop 46 & 2 & 64 to 241 & 1840 \\
\hline Fop 48 & 3 & 64 to 241 & 1968 \\
\hline
\end{tabular}

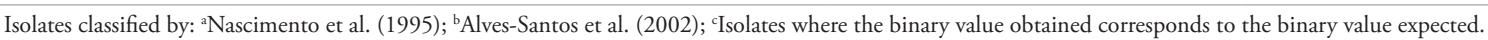

to use the same differentiating cultivars described in the literature, since a number of studies were performed with these genotypes; they are also sufficient to describe the physiological variability of FOP.

Importantly, the fungus Fusarium, a microorganism with predominantly asexual reproduction, shows no variation due to meiotic recombination. Under certain circumstances it can have a parasexual cycle, creating new gene combinations that generate genetic variability in the pathogen. It is known that this cycle consists of 3 stages: anastomosis (fusion of haploid hyphae), heterokaryosis (cells with 2 nuclei), and karyogamy, which is nothing other than the nuclear fusion in the cells. However, Ming et al. (1966) showed clear evidence that heterokaryosis is a common phenomenon in Fusarium fujikuroi under natural conditions and concluded that the results of these studies of heterokaryosis can be extended to other disease-causing Fusarium species. Other authors also relate the same results: analyzing molecularly the isolates of Fusarium oxysporum, they found that the isolates of the same geographic region were grouped in different similarity groups and don not have identical fingerprints (Silva et al., 2013). These results can be explained by the parasexuality created by high mutation rates, according to Fourie et al., (2009), who related the existence of the recombination between lineages of Fusarium oxysporum and the relations between VCGs that occurred because of the genome similarity with the evidence of heterokaryosis.

Moreover, the continuous cultivation of common bean under high inoculum potential may be associated with a more frequent heterokaryosis than would occur in crop rotation or fallow periods between 1 bean crop and the next. In Brazil, the common bean is currently cultivated in irrigated areas, most of which are infested with $F$. oxysporum, which could facilitate the occurrence of heterokaryosis.

The differentiating genotypes and their binary values were ranked according to their susceptibility to the American race, beginning with A-211, RIZ30, BAT477, and Tenderette. Secondly, the cultivars Bush Blue Lake 274 and IPA- 6 are intermediate to the Brazilian and American races, because they are both susceptible. The cultivars IPA-1 and Preto Uberabinha are susceptible to the Brazilian race. TIB3042, Diacol Calima, and Mortiño are resistant to the American as well as Brazilian races. The genotypes Diacol Calima and Mortińo are susceptible to races 6 and 7 . The last genotype in the sequence is the one with highest resistance to the races, with susceptibility to race 6 only. By this method, the physiological races of $F$ oxysporum are no longer classified by region and are numerically labeled, similar to the classification systems of $C$. lindemuthianum. Thus, for the race classification, the values of susceptible differentiating plants are added to the isolate.

The isolates $2,12,15$, and 23 were least pathogenic because they affected only 2 cultivars, but not the same ones. If coincidence can be observed between the isolates and the physiological races, their pathogenicity should be similar and the classification of these races as well, as in isolates 18 and 19.

By this method, in the binary system proposed for the classification of physiological races of FOP, no racial pattern could be observed, and existing physiological races are not 
limited to 7. By the methods proposed in the literature, the same isolate can behave differently in each case, so that a single classification is needed to cover a greater number of races. By the proposed approach, the $28 \mathrm{FOP}$ isolates were appropriately separated in 27 standardized races, confirming the use of binary values instead of a regional classification of FOP races.

\section{ACKNOWLEDGEMENTS}

The authors thank the Brazilian Federal Agency for Support and Evaluation of Graduate Education (CAPES) for the scholarships and the National Council for Scientific and Technological Development (CNPq) and State of São Paulo Research Foundation (FAPESP) for funding this research.

\section{REFERENCES}

Alves-Santos, F. M., Benito, E. P., Eslava, A. P., \& Díaz-Mínguez, J. M. (1999). Genetic diversity of Fusarium oxysporum strains from common bean fields in Spain. Applied and Environmental Microbiology, 65, 3335-3340. PMid:10427016.

Alves-Santos, F. M., Cordeiro-Rodrigues, L., Sayagues, J. M., MartinDominguez, R., Garcia-Benavides, P., Diaz-Minguez, J. M., \& Eslava, A. P. (2002). Pathogenicity and race characterization of Fusarium oxysporum f.sp. phaseoli isolates from Spain and Greece. Plant Pathology, 51, 605-611. http://dx.doi.org/10.1046/j.1365-3059.2002.00745.x.

Bao, J. R., Fravel, D. R., O’Neill, N. R., Lazarovits, G., \& Berkum, P. V. (2002). Genetic analysis of pathogenic and nonpathogenicFusarium oxysporum from tomato plants. Canadian Journal of Botany, 80, 271 279. http://dx.doi.org/10.1139/b02-004.

Cândida, D. V., Costa, J. G. C., Rava, C. A., \& Carneiro, M. S. (2009). Controle genético da murcha do fusário (Fusarium oxysporum) em feijoeiro comum. Tropical Plant Pathology, 34, 379-384.

Costa, A. F., Coelho, R. A., No., \& Miranda, P. (1989). Método de inoculação de Fusarium oxysporum f. sp. phaseoli em feijão visando seleção de linhagens resistentes. Fitopatologia Brasileira, 14, 135.

Empresa Pernambucana de Pesquisa Agropecuária - IPA. (1996). Feijão IPA-6. In: Empresa Pernambucana de Pesquisa Agropecuária - IPA. Cultivares recomendadas pela Empresa IPA. Pernambuco: IPA.

Fourie, G., Steenkamp, E. T., Gordon, T. R., \& Viljoen, A. (2009). Evolutionary relationships among the Fusarium oxysporum $\mathrm{f}$. sp. cubense vegetative compatibility groups. Applied and Environmental Microbiology, 75, 4770-4781. http://dx.doi.org/10.1128/AEM.0037009. PMid: 19482953

Ito, M. F., Carbonell, S. A. M., Pompeu, A. S., Ravagnani, R. C., Lot, R. C., \& Rodrigues, L. C. N. (1997). Variability ofFusarium oxysporum f. sp. phaseoli. Fitopatologia Brasileira, 22, 270-271.

Karimian, B., Javan-Nikkhah, M., Abbasi, M., \& Ghazanfari, K. (2010). Genetic diversity of Fusarium oxysporum isolates from common bean and distribution of mating type alleles. Iranian Journal of Biotechnology, 8, 90-97.

Leslie, J. F., \& Summerell, B. A. (2006). The Fusarium Laboratory Manual. United Kingdom: Blackwell Publishing. http://dx.doi. org/10.1002/9780470278376.

Ming, Y. N., Lin, P. C., \& Yu, T. F. (1966). Heterokaryosis in Fusarium fujikuroi (Saw.) Wr. Scientia Sinica, 15, 371-378. PMid:5933025.

Miranda, P., Costa, A. F., Reis, O. V., \& Gonçalves, M. C. (1996). Behavior of promising lines of beans (Phaseolus vulgaris L.). Pesquisa Agropecuária Pernambucana, 9, 11-17.

Nascimento, S. R. C., Kurozawa, C., \& Maringoni, A. C. (1995). Evaluation of physiological races of Fusarium oxysporum f. sp. phaseoli. Fitopatologia Brasileira, 20, 214-217.

Nelson, P. E., Tousson, T. A., \& Marasas, W. F. (1983). Fusarium species: an illustrated manual for identification. Pennsylvania: Pennsylvania State University.

Pereira, J. M., Vieira, R. F., \& Marrara, L. O. (2002). Reação de cultivares e linhagens de feijão à murcha de Fusarium. Revista Ceres, 49, 71-74.

Ribeiro, R. L. D., \& Hagedorn, D. J. (1979a). Screening for resistance to and pathogenic specialization of Fusarium oxysporumf. sp. phaseoli, the causal agent of bean yellows. Phytopathology, 69, 272-276. http:// dx.doi.org/10.1094/Phyto-69-272.

Ribeiro, R. L. D., \& Hagedorn, D. J. (1979b). Inheritance and nature of resistance in beans to Fusarium oxysporum f. sp. phaseoli. Phytopathology, 69, 859-861. http://dx.doi.org/10.1094/Phyto-69-859.

Salgado, M. O., \& Schwartz, H. F. (1993). Physiological specialization end effects of inoculum concentration on Fusarium oxysporum f. sp. phaseoliin common beans. Plant Disease, 77, 492-496. http://dx.doi. org/10.1094/PD-77-0492.

Salgado, M. O., Schwartz, H. F., \& Brick, M. A. (1995). Inheritance of resistance to a Colorado race of Fusarium oxysporum f. sp. phaseoli in common beans. Plant Disease, 79, 279-281. http://dx.doi. org/10.1094/PD-79-0279.

Sartorato, A., \& Rava, C. A. (1994). Murcha ou amarelecimento de Fusarium. In A. Sartorato, \& C. A. Rava (Eds.), Major diseases of common bean and their control (p. 175-190). Brasília: Embrapa-SPI.

Silva, A. D. S., Oliveira, E. J. D., Haddad, F., Jesus, O. N. D., Oliveira, S. A. S. D., \& Costa, M. A. P. D. C. (2013). Molecular fingerprinting of Fusarium oxysporum f. sp. passiflorae isolates using AFLP markers. Scientia Agricola, 70, 108-115. http://dx.doi.org/10.1590/S010390162013000200008.

Wendland, A., Möller, P. A., Cortes, M. V. B., Lobo, M., Jr., Melo, L. C., Pereira, H. S., Costa, G. C., \& Faria, L. C. (2012). Novas raças de Fusarium oxysporum f. sp. phaseoli identificadas via detecçáo específica por PCR. Summa Phytopathologica, 38.

Woo, S. L., Zoina, A., Del Sorbo, G., Lorito, M., Nanni, B., Scala, F., \& Noviello, C. (1996). Characterization of Fusarium oxysporumf. sp. phaseoliby pathogenic races, VCGs, RFLPs and RAPD. Phytopathology, 86, 966-973. http://dx.doi.org/10.1094/Phyto-86-966. 